\title{
Changing Pragmatics of the Indian Pharmaceutical Industry in the Pre and Post TRIPS Period
}

\author{
Ravi Kiran \\ School of Management \& Social Sciiences, Thapar University \\ Patiala 147004, India \\ Tel: 91-0175-2393-080Ｅ-mail: kiranravee@gmail.com \\ Sunita Mishra \\ Department of Humanities \& Social Sciences, M.M. University, Mullana (Ambala) \\ E-mail: sunita_mmu@yahoo.com
}

\begin{abstract}
The agreement on Trade-Related Aspects of Intellectual Property-Rights (TRIPS) is an international treaty by the World Trade Organisation (WTO) which sets down minimum standards for most form of intellectual property (IP) regulation within all member countries of the World Trade Organization. As a result of TRIPS the Pharmaceutical industry has witnessed significant changes. There has been a paradigm shift in the policies and programs governing Indian pharmaceutical industry. Against this background, the paper tries to study the Post TRIPS Patenting, Exports and R\& D Scenario in Pharmaceutical Industry of India. The study uses primary as well as secondary data to visualize the changes in the pharmaceutical industry in post-TRIPS period. The results of the study highlight that the new patent regime has encouraged innovation and greater investment in R\&D. Patents are the most efficacious and indispensable tool to secure strategic competitive advantage in the market. The impact of TRIPS compliance is becoming increasingly visible, on the pharmaceutical industry in India.
\end{abstract}

Keywords: Trade related aspects of intellectual property rights, General agreement on trade and tariff, World trade organisation, Intellectual property

\section{Introduction}

The Indian pharmaceutical has expanded drastically in the last two decades. The Pharmaceutical and Chemical industry in India is an extremely fragmented market with severe price competition and government price control. The Pharmaceutical industry in India meets around 70\% of the country's demand for bulk drugs, drug intermediates, pharmaceutical formulations, chemicals, tablets, capsules, orals and injectibles. There are approximately 250 large units and about 8000 Small Scale Units, which form the core of the pharmaceutical industry in India. The Indian pharmaceutical industry, which had little technological capabilities to manufacture modern drugs locally in the 1950s, has emerged technologically as the most dynamic manufacturing segment in the Indian economy in the 1990s (Kumar and Pradhan 2003). When the product patents on Pharmaceutical products were abolished in India in 1972, the Indian industry was not a significant player either in the domestic or the overseas market. It was largely confining its activities to reverse engineering and thriving on developing new processes for the existing products and catered mostly to the domestic market.

In the last two decades, the Pharmaceutical companies have gained a firm footing in the market, their share of the domestic market has risen from 10 per cent in the early 1970s to over 80 per cent now. India has also emerged as a major supplier of drugs to the international markets, particularly over the past decade. A major factor that contributed to the rapid growth of the Pharmaceutical industry is that through skilful innovations in production processes, the Indian companies could make cheap copies of patented drugs and sell them at very low prices compared to anywhere else in the world. However, this favourable business environment will now undergo a change to favour drug MNCs because of their size and heavy R\&D budgets. 
Under the new IPR regime, the challenge for Indian small pharmaceutical firms is to remain innovative as they were under the earlier regime. Under the Indian Patent Act 1970, small firms with their resource limitation had relied primarily on outside sources of R\&D like products of foreign firms and effectively invested their limited internal R\&D fund for reverse engineering and developing cost effective processes. However, the implementation of the World Trade Organization (WTO) agreement on the Trade Related Intellectual Property Regime (TRIPS) had led to a number of radical changes in the Indian IPR regime. Three Amendments in March 1999, June 2002 and April 2005 on the Patent Act 1970 has been carried out to bring Indian patent regime in harmony with the requirements of TRIPS. These new policies have a number of implications for the survival and growth of small pharmaceutical firms today.

This new IPR regime had extended patent protection to products in drugs, food and chemicals sectors, besides increasing the duration of patent term to 20 years. The burden of proof has been reversed in the case of a process patent and patent owner may not produce the product locally. In the above backdrop, the present study examines the impact of TRIPS on small pharmaceutical firms relative to large pharmaceutical firms in terms of the parameters: This involves comparative analysis of $R \& D$, Patents \& Exports of small firms vis-à-vis large firms. The study also explores the implications of new policy regime for small pharmaceutical firms. The study uses both primary as well as secondary data.

\section{Review of literature}

Sunil (2006) in his working paper undertakes a detailed mapping out of the sectoral system of innovation of India's pharmaceutical industry. He concludes that the TRIPS compliance of the intellectual property right regime has not reduced the innovation capacity of the domestic pharmaceutical industry which has visualized an increase in both research budget and patenting. But at the same time it has not made them work on R\&D projects that may lead to the discovery of drugs for neglected diseases of the developing world. He feels that this is an area where public policy support is still required.

Bhaduri (2006) has tried to examine the justification of some of the arguments advanced to implement TRIPS in India. She argues that extending monopoly rights up to 20 years can lead to a situation, where complacency effect of a monopolist, arising out of a secure market, could lead to a decline in R\&D expenditure because it will have no incentive to search for more efficient processes of the same product during the patent life. The consumers may, therefore, have to pay higher prices for inefficient processes of the novel drugs under the TRIPS which is in sharp contrast with the stated objectives of the WTO, which propagates to raise global cost efficiency and thereby consumer welfare

In his working paper, Chaudhuri (2007) explores that $R \& D$ expenditure has dramatically increased for a segment of the Indian pharmaceutical industry after TRIPS came into effect. It is not only that the amount of R\&D expenditure has increased, but there has been a drastic shift in the structure of R\&D activities of the Indian companies. Earlier they were primarily engaged with the development of new processes for manufacturing drugs, now they are also involved in R\&D for new chemical entities (NCE). Although, the R\&D activities have diversified, but the Indian pharmaceutical firms have yet to prove their competence in innovating new products. No NCE has yet been developed.

The study by Zuniga \& Combe (2002) focuses on the economic impact of patent protection of pharmaceuticals in the Mexican industry. The researchers have tried to make a brief evaluation of the static and dynamic effects of the introduction of patent protection for pharmaceuticals in Mexico and to compare them to those predicted by economic literature. Although the static effects might have been limited since multinationals already controlled the private market before the reforms, dynamic gains are still far from being felt. Reinforcing patent protection will not automatically change the access and the ways to finance R\&D projects. They suggest that other factors besides patent protection must be taken into account before expecting an increased R\&D activity in the Mexican pharmaceutical sector

The study by Lanaszka (2003) highlights that WTO rules on IPRs are controversial because of the persistence of the asymmetry in the level of development and research capacities between the developed and developing countries. It is of course true that exploitative business practices are possible only to the extent that monopoly positions are tolerated. Many developing countries, however, lack the necessary financial resources and have not yet developed appropriate competition rules to deal effectively with the challenges presented by TRIPS agreement. The leading industrialized countries must pay attention to the social and economic needs of the developing countries for which a change of attitude is necessary. It should begin with the idea of fairness as one of the principles governing the dialogue between the developed and developing countries. Farness entails sensitivity to the special needs of developing countries and one important dimension of this sensitivity is the recognition of the problems posed by human needs, such as health.

The review of earlier studies highlight that there is an urgent need to carry out research on Indian Pharmaceutical industry in view of the changes taking place in view of globalisation, liberalisation and privatization, especially in view of TRIPS. This study specifically deals with the pharmaceutical industry in the North-Western India colleting data from 100 firms with the following broad objectives to analyse Post TRIPS Scenario in Pharmaceutical industry of India by: 
1) analysing the $R \& D$ in Pharmaceutical industry of India in the post TRIPS Period .

2) analysing the patenting activity in Pharmaceutical industry of India in the Post TRIPS Period.

3) analysing the exports in the post TRIPS Period in Pharmaceutical

\section{Data Collection and Methodology}

The study used both primary and secondary data for analysis. The sources of secondary data are Indiastat.com, EPO, DST and Govt Reports. For primary data around 180 firms were approached and 110 firms returned the questionnaire. Out of these $100(55.6 \%)$ questionnaires were complete in all respects and have been taken up for analysis. The data has been collected from: Mohali, Dehra Bassi, Lalru in Punjab, Baddi, Kala Aamb in Himachal Pradesh, Ambala in Haryana. From the total of 100 pharmaceutical firms surveyed, 8 were large scale firms, 24 medium scale firms and 68 were small scale firms.

To obtain the primary data, questionnaire method was adopted. Judgment sampling method has been adopted for the selection of the pharmaceutical companies. Table I shows the sampling distribution

\section{Data Analysis}

All the 100 firms surveyed were producing only formulation. Small pharmaceutical companies produce only formulations as they are not in a position to afford the heavy investment required for the production of bulk drugs. Medium companies generally prefer to produce formulation because profit margin is higher. Large pharmaceutical companies can produce both. However the sample firms in this study covering both the medium \& the large scale units were producing formulations only. These units were mainly set up in excise free zones like Baddi, Kala Amb etc.

\subsection{Changing Scenario of Pharmaceutical Industry}

The trends of Pharmaceutical Industry depict that formulations contribute a major share. In 1980-81 the share of Bulk drugs was only 240 crores $(16.7 \%)$ whereas the share of formulations was 1200 crores $(83.33 \%)$. Over the years while the share of bulk drugs has increased to 9034 crores, the share of formulations has increased to 31946 crore, formulations still are contributing a major share (78\%). The results of the present survey of 100 firms from North -Western India also depicted that all the 100 firms were producing formulations. (Table 2)

Indian Govt. had declared certain areas like Baddi and Kala Amb as excise free zones. Table 3 depicts the relation between size and total sales. $100 \%$ of the large scale firms have reported substantial increase in sales in the last 1 year. (Table 3) These firms have maintained the same status in the last five years also. (Table 4) $67 \%$ of the medium scale firms have reported substantial increase whereas 33\% have reported marginal increase in sales in the last 1 year. However in the last five years, $83 \%$ of the firms have reported substantial increase, whereas $17 \%$ have reported marginal increase in sales. $44 \%$ of the small scale firms have reported substantial increase in sales whereas $53 \%$ have reported marginal increase in sales in the last 1 year.

All the large scale firms responded that their share in domestic market is not declining (Table 5). This percentage was $83 \%$ in case of medium firms as $17 \%$ reported a decline in share in domestic market. In case of small firms $17 \%$ felt that their share in domestic market was declining.

All the 8 large scale firms were focusing on exports. 33\% of the medium sized firms were focusing on export, whereas the same was not true for Small scale firms. (Table 6)

The large and the medium scale firms agree with the view that they have shifted to better technology. $11.8 \%$ of small firms don't accept this view and $23.5 \%$ are neutral about it. Overall even in small scale segment the firms who accept this view are higher than those who disagree with it. (Table 7)

4.2 Firm size and schedule M: Majority of the companies were not against Schedule M. When asked about whether schedule $\mathrm{M}$ was a hasty decision on the part of the govt. $50 \%$ of the large scale firms strongly disagree, whereas $50 \%$ were neutral about it. From medium size firms 33\% strongly disagree, $17 \%$ disagree and $33 \%$ were neutral. Only $17 \%$ agreed that it was a hasty decision on the part of the govt. Even from small size firms, only $18 \%$ firms agreed that it was a hasty decision on the part of the govt. $29 \%$ strongly disagree with the view, $35 \%$ disagree and $18 \%$ were neutral. Not even a single firm out of the three categories strongly agreed that Schedule $\mathrm{M}$ was a hasty decision on the part of the govt. (Table 8)

4.3 Firm size \& In-House $R \& D$ : In the context of new policy regime, technology and productivity are most important determinants of survival and competitiveness of pharmaceutical firms. Even the small firms are required to urgently upgrade their internal sources of technology like expanding in house R\&D activities, employing more skilled labour, providing training to their technical manpower, etc. As far as R\&D intensity is concerned, it can be certainly predicted that small pharmaceutical firms considerably lagged behind their large counterparts in undertaking innovative activities. (Table 9) 
All large scale firms agreed that In-house R \& D has shown a substantial Increase. 83.3\% medium scale responded that In-house $\mathrm{R} \& \mathrm{D}$ has shown a marginal Increase and $16.7 \%$ accepted that it has substantially increased. 24 small firms are of the view that In- House R\&D has not changed, while 36 are of the view that it has marginally increased while 12 Small firms responded that it has increased substantially. 12 percent of small firms responded that it had marginally decreased. The value of Chi Square is $83.077^{* *}$ (Df: 8) is significant at 1 percent level, which depicts that there is a significant association between firm size and In- House R\&D.

The large firms rated their R\&D performance as very high or high. Four medium firms rated it as very high, eight firms rated it as high, while 12 firms felt that the performance was low. Only eight out of 68 small firms rated performance as high and very high, while thirty firms were of the view that performance was low or very low. Value of Chi Square is: $45.916^{*}$,df: 8 , which again depicts that there is a strong association between firm size and performance of R\&D. (Table 10)

There was an overall agreement amongst all the large scale firms that the proportion of turnover spent on R\&D in the last few years has substantially increased (Table 11). Out of 24 medium firms twenty were of the view that proportion of turnover spent on R\&D in the last few years has marginally increased and four firms accepted that it had substantially increased. The response was not similar for the small scale firms. In fact twelve of the firms responded that it had decreased and there were 24 firms who accepted that it had increased marginally. Chi- Square is $91.325^{* *}$ (df: 8) depicts a relationship between firm size and the proportion of turnover spent on R\&D.

\section{Impact of TRIPS on Indian Pharmaceutical Sector}

Factor analysis was done to study the Impact of TRIPS on Indian Pharmaceutical Sector (Table 12). The results highlight that six factors namely: i) TRIPS, R\& D and New Opportunities, ii) Products under DPCO and Performance of R\& D iii) Product Category, Nature of order \& Threats, iv) Changes in Tech. and Tech Personnel Employed, v) Changes in Total Sales and exports and vi) Preparedness for TRIPS extracted together account for 76.39 percent of variation.

Factor I viz. TRIPS, R\& D and New Opportunities consists of: i.) In-house R\&D activities with loading of .804, ii.) Proportion of turnover spend on R\&D in the last few years (.663), iii) Cost of production as a result of signing of TRIPS (.690), iv.) Impact of TRIPS on various issues related to Indian pharmaceutical industry (.777) and v) New Opportunities created due to TRIPS (.779).

Two components in this factor are important namely: i.) In-house R\&D activities and ii.) Cost of production as a result of signing of TRIPS. Both these components had mean $3.72 \& 3.76$ which is higher than factor mean of 2.93. It shows that though the cost of production has increased as a result of signing TRIPS, but at the same time In-house R\&D activities has also increased.

Second factor viz. Products under DPCO and Performance of R\& D had a Eigen value of 2.561 with a variance of $15.067 \%$. Two components of this factor are: i.) Impact on the no. of products of the firm covered under Drugs Price Control Order [DPCO](.891) and ii.) Performance of R\&D activities (.794). Based on mean score the factor Impact on the no. of products of the firm covered under Drugs Price Control Order [DPCO] had a mean score of 3.36 which was higher than mean score of both the factors (3.30).

Third factor that emerged from the factor analysis is Product Category, Nature of order \& Threats with Eigen value of 2.085. This explained $12.263 \%$ of variance. The components of this factor are: i.) Impact on no. of products introduced by the firm (.926), ii.) Threats due to TRIPS in the form of big competition from foreign companies (.857) and iii.) Bulk orders from big companies in the last 10 years (.550). Two components viz. Impact on no. of products introduced by the firm in the last 10 years having a mean score of 4.20 and Threats due to TRIPS in form of big competitions from foreign companies having a mean score of .3 .30 are important. Both these components had higher mean than factor mean of 3.12. It shows that inspite of the threats due to TRIPS in form of severe competitions from foreign companies, number of products introduced by the firm in the last 10 years has increased.

Fourth factor namely Changes in Tech. and Tech Personnel Employed had Eigen value of 1.653 and this factor explained $9.722 \%$ of variance. Two components of this factor are: i.)Shift to better technology due to TRIPS (.857) and ii.) Total technical persons employed (.618). Out of these two components, Shift to better technology due to TRIPS is more important, as it has factor loading of .867. and mean score of 3.96 which is higher than the factor mean 3.60. This is quite obvious as majority of the respondents gave a positive reply to this question.

Fifth factor viz. Changes in Total Sales and exports had an Eigen value of 1.324. This factor explained 7.789\% of variance. This factor has two variables: i.) Sales in last few years (.861) and ii.) Exports in last few years (582). Out of these two factors Sales in last few years with a mean score of 4.30 has been higher than the mean score of this factor (4.13). It shows that as a result of signing TRIPS, sales in the last few years have been definitely increased. 
The last factor that emerged from factor analysis has been Preparedness for TRIPS. This factor had an Eigen value of 1.009 and explained $5.936 \%$ of variation. This factor covered two variables, namely, i.) Status of Patents (.788) and ii.) Face challenges posed by TRIPS (.781).

Status of Patents had a relatively higher mean score (4.14) than the factor mean which is 3.95.It might be due to the reason that the patents of all large \& medium firms have registered an increase in post Trips period.

The Overall Mean of all Factors is 3.37. Three important factors on the basis of ranking on mean score include: i) Changes in Total Sales and exports ii) Preparedness for TRIPS, and iii) Changes in Tech. and Tech Personnel Employed. The results of factor analysis highlight that patenting, sales and switch to new technology have higher impact on the Pharmaceutical industry of India.

\subsection{Some Leading Pharmaceutical Firms}

The study will be incomplete without focusing upon the few Leading Pharmaceutical Firms to see how they are performing in the post TRIPS period. (Table 13)

\subsection{Glimpse of the World wide Patent Filing by leading Pharmaceutical Firms}

For patent filing the three top firms have shown a marked variation. Ranbaxy has preferred to file patents in EPO. The firm had applied for 73 patents during 2005, 72 being filled in EPO. Dr. Reddy's has preferred to file patents in US has been the major area of interest with the firm having made patent 31 applications during 2005. Cipla has applied for patents in countries other than in the US or EPO member states. The overall rate of Growth of patent filing has been 1.86 per annum in the period 1999 to 2006 . Since 2001 there has been a rapid rise in patent filing by leading Pharmaceutical Firms. (Table 14)

The industry's exports were worth 122 crores in 1981-82 and increased to 24942 crores in 2006-07 increasing at an annual growth rate of 9.02 percent. The growth rate was 4.90 in Pre-TRIPs period and 5.03 percent in Post-TRIPS period. (Table 15)

Expenditure on $\mathrm{R} \& \mathrm{D}$ by the Indian pharmaceutical companies is around $1.9 \%$ of the industry's turnover. This is very low when compared to the investment on R \& D by foreign research-based Pharmaceutical companies. They spend $10-16 \%$ of the turnover on R \& D. However, now that India has entered into the Patent protection area, many companies are spending relatively more on $\mathrm{R} \& \mathrm{D}$.

With the reintroduction of product patents, leading Indian pharmaceutical are placing greater focus on $R \& D$ and the discovery of new chemical entities. Traditionally, the vast majority of India's pharmaceutical R\&D spending was concentrated on reverse engineering and the adaptation of patented foreign drugs to the Indian market. Most of the industry's funding went to research rather than to new drug discovery and development. After 2005, India's leading drug companies recognized that they could not survive as global players without significant R\&D capabilities. R\& D Expenses have increased at a higher rate in the Post- TRIPs period growing at a rate of 5.07 against 3.88 in period I. Overall rate of growth of R\& D has been 6.05 in the period 1981-82- 2006-07.

Patenting scenario of the Pharmaceutical industry also depicts a change in the patenting culture with the patents in drugs and Pharmaceutical Industry Growing at higher a rate (6.06\%) as against the $5.57 \%$ growth of total patents granted. Not only patent filing is increasing, patent granted is also growing. Patents Granted to Drugs \& Pharmaceuticals as a percentage of Total Patents Granted varied between 7.828 to $22.63 \%$. (Table 16)

\section{Conclusion}

The broad objectives of the study are to analyse Post TRIPS Scenario in Pharmaceutical industry of India by analysing the patenting activity, R\&D and Exports in Pharmaceutical industry of India in the Post TRIPS Period. The results reveal an increase in sales, exports, Patents and R\& D in the Post TRIPs period. Patent filing as well as patents granted has shown an increase. Patents in Drugs and pharmaceuticals have grown at a faster rate as compared to total patents granted. Patent filing by leading Pharmaceutical companies has also improved. US and EPO are the preferred destinations for patent filing.

Size wise analysis depicted that all the large scale firms, majority of medium and small scale firms reported a substantial increase in sales in the last year. The results of Chi Square depict a significant association between firm size and In- House R\&D, i.e., as the size of the firm increases, its In- House R\&D activities also increase. At the same time results of Chi Square again depict that there is a strong association between firm size and performance of R\&D,

i. e., as the firm size increases, the performance of R\&D also improves. All firms small as well as large agree that R\& D activity in the post-TRIPS period has increased.

The pharmaceutical industry in India had been subjected to rigorous price controls since 1970 through the adoption of the Drugs Price Control Order or DPCO. The DPCO was aimed at fulfilling the objective to ensure that availability of drugs at reasonable prices in India and to ensure incentives for domestic producers to produce new formulations. In the 
1980s, the focus of the Drug Policy adopted by the Government has been more on providing market-based incentives to the Indian pharmaceutical industry. The analysis depicts that Indian pharmaceutical companies are still focusing more on Formulations and less of bulk drugs.

Factor analysis of Impact of TRIPS on Indian Pharmaceutical Sector revealed that Six factors namely: i) TRIPS, R\& D and New Opportunities, ii) Products under DPCO and Performance of R\& D iii) Product Category, Nature of order \& Threats, iv) Changes in Tech. and Tech Personnel Employed, v) Changes in Total Sales and exports and vi) Preparedness for TRIPS extracted together account for 76.39 percent of variation.

The Overall Mean of all Factors is 3.37. Three important factors on the basis of ranking on mean score include: i) Changes in Total Sales and exports ii) Preparedness for TRIPS, and iii) Changes in Tech. and Tech Personnel Employed. The results of factor analysis underscore the fact that sales, patenting and switch to new technology had higher impact on the Pharmaceutical industry of India. These three factors had a mean score of 4.13, 3.95 and 3.60 which is higher than overall factor mean of 3.37 .

The results revealed a tendency to shift to excise free zones. Sales, Exports, R\&D and Patenting have increased in the Post-TRIPS period. The large and the medium scale firms accepted of having shifted to better technology. So the Pharmaceutical Industry of India is changing itself to suit the global Scenario.

\section{Limitations of the Study}

This study is mainly based on the primary data collected through questionnaire from various pharmaceutical companies situated in Northwest region. The researcher has collected the primary data by mailing one/ two questionnaires followed by repeated reminders and also by visiting the concerned pharmaceutical companies. Still the response rate was not very high. In several cases, the exact meaning of the questions (or) may be its impact were not understood by the respondents and they were left unanswered. In large scale companies the executives of the sample pharmaceutical companies responding the questionnaire were not in a position to reply on all the three parameters, i.e., patents, export \& R\&D.

\section{Future Scope}

The study should focus more on firm level analysis finding the linkages between Technology, Exports, R\& D and Patenting. The study for Primary data covers the North West Region only. It should be extended to cover entire India.

\section{References}

Abrol, D. (2004). Knowledge Diffusion under the Emerging Post TRIPS Indian Pharmaceutical Scenario. Paper presented at the DRUID Summer Conference 2004 on Industrial Dynamics, Innovation and Development Elsinore, Denmark. [Online] Available: http://www2.druid.dk/conferences/viewpaper.php?id=2460\&cf=16 (retrieved From June 14-16)

Bhaduri, S. (2006). Trips in India: Reasons and Rhetorics' Vidyasagar University. Journal of Commerce, current issue, Vol. 11, pp. 28-38.

Chadha, A. (2005). TRIPS and Patenting Activity: Evidence from the Indian Pharmaceutical Industry. National University of Singapore, Department of Economics, working paper no 0512 [Online] Available: http://nt2.fas.nus.sg/ecs/pub/wp/wp0512.pdf

Chaudhuri, S. (2007). Is Product Patent Protection Necessary in Developing Countries for Innovation? R\&D by Indian Pharmaceutical Companies after TRIPS' Working Paper Series WPS No. 614 . [Online] Available:http://www.iimcal.ac.in/res/upd/Sudip\%20Wp\%20614.pdf (Retrieved From September 2007)

Chaudhuri, S. (2002). TRIPS Agreement and Amendment of Patents Act in Indian. Economic and Political Weekly, Vol. 37, No. 32, pp. 3354-3360.

FICCI Report. (2005). Competitiveness of the Indian Pharmaceutical Industry in the New Product Patent Regime. FICCI Report for National Manufacturing Competitive Council.

Glasgow, L.J. (2001). Stretching the limits of intellectual property rights: has the pharmaceutical industry gone too far? IDEA - The Journal of Law and Technology, Vol. 41, No. 2, pp. 227-268.

Gupta .V.K. (2000). Trends in post WTO patenting by India in USA ' Current science. Vol. 78, No. 8, pp. 955-966.

Kiran, R. (2004). Changing Patent Scenario in India. Business Perspectives- Special 1ssue on IPR, Vol., No. 1. Jan-Jun, pp. 33-42.

Lalitha, N. (2002). Indian Pharmaceutical Industry in WTO Regime: A SWOT Analysis. Economic and Political Weekly, Vol. 37, No. 34, pp. 3542-3555.

Lalitha N. (2002). Drug Policy 2002: Prescriptions for symptoms. Economic and Political Weekly, Vol.37, No.30, pp. 3102-3104.

Lall S.and Albaladejo M. (2002). Indicators of the Relative Importance of IPRs in Developing Countries' QEH Working Paper Series - QEHWPS8.oxford. [Online] Available: http://www3.qeh.ox.ac.uk/pdf/qehwp/qehwps85.pdf Lanaszka, A. (2003). The Global Politics of Intellectual Property Rights and Pharmaceutical Drug Policies in Developing Countries. International Political Science Review, Vol. 24, No. 2, pp.181-197. 
Lanjouw, J. (1998). The Introduction of Pharmaceutical Product Patent in India: Heartless Exploitation of the Poor and Suffering? NBER Working Paper, No. 6366. [Online] Available: http://www.nber.org/papers/w6366

Mani, S. (2006). The Sectoral System of Innovation in Indian Pharmaceutical Industry. Working Paper, 382. [Online] Available: http://cds.edu/download_files/wp382.pdf.

Pradhan, J. P. (2003). Liberalization, Farm size and R\& D Performance: A Firm Level Study of Indian Pharmaceutical Industry, RIS -DP 40/2003.

Pradhan, J.P. (2004). Strengthening Intellectual Property Rights Globally: Impact on Indian Pharmaceutical Exports', J.N.U., New Delhi. 2004. [Online] Available: http://www.ris.org.in/dp40 pap.pdf

Pradhan,J.P. (2007). New Policy Regime and Small Pharmaceutical Firms In India. ISID Working Paper, No. $2007 / 02$ [Online] Available: http://isidev.nic.in/pdf/wp0702.pdf

Raju,K.D. (2004). WTO-TRIPS Obligations and Patent Amendments in India: A Critical Stocktaking. Journal of Intellectual Property Rights, Vol. 9, No. 3, pp. 226-241.

Ramanna, A. (2002). Policy Implications of India's Patent Reforms: Patent applications in the post-1995 era. Economic and Political weekly, Vol.37, No.3, pp. 2065-2075.

Sampath,G. (2005). Economic Aspects of Access to Medicines After 2005: Product patent Protection and Emerging Firm Strategies in the Indian Pharmaceutical Industry. Intech Publications. [Online] Available: http://www.whoint/entity/intellectual Property/Studies / Padmashree Sampath Final. Pdf

Sampath , G. (2006). India's Product Patent Protection Regime: Less or More of 'Pills for The Poor?' Working paper Series, \#2006-019. [Online] Available: http:/www.merit.unu.edu/publications/wppdf/2006/wp2006- 019.pdf

Tancer, R. (1999). Investing in the Indian pharmaceutical industry. The American Graduate school of International Management, 1999, Thunderbird. [Online] Available:http://www.thunderbird.edu/pclf/ case series/a03990015.PAF

Zuniga, Z.P. \& Combe, E. (2002). Introducing product patent in pharmaceutical sector: A first evaluation of the Mexican Case Region et Development, Vol.0, No. 16, pp. 191-221.

Table 1. Pharmaceutical Companies

\begin{tabular}{|c|c|c|}
\hline S. No & Place of Pharmaceutical Companies & No. of units \\
\hline 1. & Mohali & 6 \\
\hline 2. & Dehra Bassi & 6 \\
\hline 3. & Lalru & 27 \\
\hline 4. & Baddi & 30 \\
\hline 5. & Kala Amb & 25 \\
\hline 6. & Ambala & 100 \\
\hline
\end{tabular}


Table 2. Production (Rs Crores) (1965-66 to 2004-2005)

\begin{tabular}{|c|c|c|c|c|c|}
\hline Year & Bulk Drugs & Formulations & Total & $\begin{array}{c}\text { \%age share of } \\
\text { bulk drugs }\end{array}$ & $\begin{array}{l}\% \text { share of } \\
\text { formulations }\end{array}$ \\
\hline $1980-81$ & 240 & 1200 & 1440 & 16.7 & 83.33 \\
\hline $1981-82$ & 289 & 1434 & 1723 & 16.8 & 83.23 \\
\hline $1982-83$ & 345 & 1660 & 2005 & 17.2 & 82.79 \\
\hline $1983-84$ & 355 & 1760 & 2115 & 16.8 & 83.22 \\
\hline $1984-85$ & 377 & 1827 & 2204 & 17.1 & 82.89 \\
\hline $1985-86$ & 416 & 1945 & 2361 & 17.6 & 82.38 \\
\hline $1986-87$ & 458 & 2140 & 2598 & 17.6 & 82.37 \\
\hline $1987-88$ & 480 & 2350 & 2830 & 17 & 83.04 \\
\hline $1988-89$ & 550 & 3150 & 3700 & 14.9 & 85.14 \\
\hline $1989-90$ & 640 & 3420 & 4060 & 15.8 & 84.24 \\
\hline $1990-91$ & 730 & 3840 & 4570 & 16 & 84.03 \\
\hline $1991-92$ & 900 & 4800 & 5700 & 15.8 & 84.21 \\
\hline $1992-93$ & 1150 & 6000 & 7150 & 16.1 & 83.92 \\
\hline 1993-94 & 1320 & 6900 & 8220 & 16.1 & 83.94 \\
\hline 1994-95 & 1518 & 7935 & 9453 & 16.1 & 83.94 \\
\hline $1995-96$ & 1922 & 9125 & 11047 & 17.4 & 82.60 \\
\hline $1996-97$ & 2186 & 10494 & 12680 & 17.2 & 82.76 \\
\hline $1997-98$ & 2623 & 12068 & 14691 & 17.9 & 82.15 \\
\hline 1998-99 & 3148 & 13878 & 17026 & 18.5 & 81.51 \\
\hline $1999-2000$ & 3777 & 15960 & 19737 & 19.1 & 80.86 \\
\hline $2000-01$ & 4533 & 18354 & 22887 & 19.81 & 80.19 \\
\hline 2001-02 & 5439 & 21104 & 26543 & 20.49 & 79.51 \\
\hline $2002-03$ & 6529 & 24185 & 30714 & 21.26 & 78.74 \\
\hline 2003-04 & 7729 & 27692 & 35421 & 21.82 & 78.18 \\
\hline 2004-05 & 9034 & 31946 & 40980 & 22.04 & 77.96 \\
\hline
\end{tabular}

Source: Indiastat.com 
Table 3. Sales in the last 1 year

\begin{tabular}{|c|c|c|c|c|c|c|}
\hline Firm Size & $\begin{array}{c}\text { Substantially } \\
\text { Decreased }\end{array}$ & $\begin{array}{c}\text { Marginally } \\
\text { Decreased }\end{array}$ & $\begin{array}{c}\text { Remained } \\
\text { Same }\end{array}$ & $\begin{array}{c}\text { Marginally } \\
\text { Increased }\end{array}$ & $\begin{array}{c}\text { Substantially } \\
\text { Increased }\end{array}$ & Total \\
\hline Large & 0 & 0 & 0 & 0 & 8 & 8 \\
\hline & $0.0 \%$ & $0.0 \%$ & $0.0 \%$ & $0.0 \%$ & $100.0 \%$ & $100.0 \%$ \\
\hline Medium & 0 & 0 & 0 & 8 & 16 & 24 \\
\hline & $0.0 \%$ & $0.0 \%$ & $0.0 \%$ & $33.330 \%$ & $66.67 \%$ & $100.0 \%$ \\
\hline Small & 0 & 0 & 2 & 36 & 30 & 68 \\
\hline & $0.0 \%$ & $0.0 \%$ & $2.9 \%$ & $52.9 \%$ & $44.1 \%$ & $100.0 \%$ \\
\hline Total & 0 & 0 & 2 & 44 & 54 & 100 \\
\hline & $0.0 \%$ & $0.0 \%$ & $2.0 \%$ & $44.0 \%$ & $54.0 \%$ & $100.0 \%$ \\
\hline
\end{tabular}

Table 4. Sales in the last 5 year

\begin{tabular}{|c|c|c|c|c|c|c|}
\hline \multirow{2}{*}{ Firm size } & \multicolumn{6}{|c|}{ Sales in the last 5 years } \\
\hline & $\begin{array}{l}\text { Substantially } \\
\text { Decreased }\end{array}$ & $\begin{array}{l}\text { Marginally } \\
\text { Decreased }\end{array}$ & $\begin{array}{c}\text { Remained } \\
\text { Same }\end{array}$ & $\begin{array}{l}\text { Marginally } \\
\text { Increased }\end{array}$ & $\begin{array}{l}\text { Substantially } \\
\text { Increased }\end{array}$ & Total \\
\hline \multirow[t]{2}{*}{ Large } & 0 & 0 & 0 & 0 & 8 & 8 \\
\hline & $0.0 \%$ & $0.0 \%$ & $0.0 \%$ & $0.0 \%$ & $100.0 \%$ & $100.0 \%$ \\
\hline \multirow[t]{2}{*}{ Medium } & 0 & 0 & 0 & 4 & 20 & 24 \\
\hline & $0.0 \%$ & $0.0 \%$ & $0.0 \%$ & $16.67 \%$ & $83.83 \%$ & $100.0 \%$ \\
\hline \multirow[t]{2}{*}{ Small } & 6 & 0 & 6 & 24 & 32 & 68 \\
\hline & $8.82 \%$ & $0.0 \%$ & $8.820 \%$ & $35.29 \%$ & $47.06 \%$ & $100.0 \%$ \\
\hline \multirow[t]{2}{*}{ Total } & 6 & 0 & 6 & 28 & 60 & 100 \\
\hline & $6.0 \%$ & $0.0 \%$ & $6.0 \%$ & $28.0 \%$ & $60.0 \%$ & $100.0 \%$ \\
\hline
\end{tabular}

Table 5. Firm Size and share in domestic market

\begin{tabular}{|c|c|c|c|}
\hline Firm size & \multicolumn{2}{|c|}{ Is the share in domestic market declining? } \\
\hline & Yes & No & Total \\
\hline Large & 0 & 8 & $100.0 \%$ \\
\hline Medium & $0 \%$ & $100.0 \%$ & 24 \\
\hline Small & $16.7 \%$ & $83.3 \%$ & $100.0 \%$ \\
\hline & 12 & 56 & $100.0 \%$ \\
\hline Total & $17.6 \%$ & $82.4 \%$ & 100 \\
\hline
\end{tabular}


Table 6. Firm Size and Focus on Exports

\begin{tabular}{|c|c|c|c|}
\hline Firm size & Yes & No & Total \\
\hline & $8(100.0 \%)$ & 0 & 24 \\
\hline Medium & $8(33.3 \%)$ & $16(66.7 \%)$ & 68 \\
\hline Small & 0 & $68(100 \%)$ & 100 \\
\hline Total & 16 & 84 & 8 \\
\hline
\end{tabular}

Table 7. Shift to better technology

\begin{tabular}{|c|c|c|c|c|c|c|}
\hline Firm Size & $\begin{array}{c}\text { Strongly } \\
\text { Disagree }\end{array}$ & Disagree & Neutral & Agree & $\begin{array}{c}\text { Strongly } \\
\text { Agree }\end{array}$ & Total \\
\hline Large & - & 0 & 0 & 4 & 4 & 8 \\
\hline & & $0 \%$ & $0 \%$ & $50.0 \%$ & $50.0 \%$ & $100.0 \%$ \\
\hline Medium & - & 0 & 0 & 20 & 4 & 24 \\
\hline & - & $0 \%$ & $0 \%$ & $83.3 \%$ & $16.7 \%$ & $100.0 \%$ \\
\hline Small & - & $11.8 \%$ & $23.5 \%$ & $35.3 \%$ & $29.4 \%$ & $100.0 \%$ \\
\hline & - & 8 & 16 & 48 & 28 & 100 \\
\hline Total & & & & & 24 & 68 \\
\hline
\end{tabular}

Table 8 . Firm size and schedule M

\begin{tabular}{|c|c|c|c|c|c|c|}
\hline \multirow{2}{*}{ Firm size } & & & \multicolumn{4}{|c|}{ Firm size and schedule $M$} \\
\hline & $\begin{array}{l}\text { Strongly } \\
\text { Disagree }\end{array}$ & Disagree & Neutral & Agree & $\begin{array}{c}\text { Strongly } \\
\text { Agree }\end{array}$ & Total \\
\hline \multirow[t]{2}{*}{ Large } & 4 & 0 & 4 & 0 & 0 & 8 \\
\hline & $50.0 \%$ & $.0 \%$ & $50.0 \%$ & $.0 \%$ & $.0 \%$ & $100.0 \%$ \\
\hline \multirow[t]{2}{*}{ Medium } & 8 & 4 & 8 & 4 & 0 & 24 \\
\hline & $33.3 \%$ & $16.7 \%$ & $33.3 \%$ & $16.7 \%$ & $.0 \%$ & $100.0 \%$ \\
\hline \multirow[t]{2}{*}{ Small } & 20 & 24 & 12 & 12 & 0 & 68 \\
\hline & $29.4 \%$ & $35.3 \%$ & $17.6 \%$ & $17.6 \%$ & $.0 \%$ & $100.0 \%$ \\
\hline \multirow[t]{2}{*}{ Total } & 32 & 28 & 24 & 16 & 0 & 100 \\
\hline & $32.0 \%$ & $28.0 \%$ & $24.0 \%$ & $16.0 \%$ & $.0 \%$ & $100.0 \%$ \\
\hline
\end{tabular}


Table 9. Firm size and In- House R\&D

\begin{tabular}{|c|c|c|c|c|c|c|c|}
\hline Firm Size & $\begin{array}{c}\text { Substantially } \\
\text { Decreased }\end{array}$ & $\begin{array}{c}\text { Marginally } \\
\text { Decreased }\end{array}$ & $\begin{array}{c}\text { Remained } \\
\text { Same }\end{array}$ & $\begin{array}{c}\text { Marginally } \\
\text { Increased }\end{array}$ & $\begin{array}{c}\text { Substantially } \\
\text { Increased }\end{array}$ & Total & \\
\hline Large & 0 & 0 & 0 & 0 & $8(100 \%)$ & 8 & $\begin{array}{c}\text { Pearson } \\
\text { Chi-Square: } \\
83.077 * \\
\mathrm{df}: 8\end{array}$ \\
\hline Medium & 0 & 0 & 0 & $20(83.3 \%)$ & $4(16.7 \%)$ & 24 & 68 \\
\hline Small & 0 & $8(11.8 \%)$ & $24(35.3 \%)$ & $36(52.9 \%)$ & 0 & 100 & \\
\hline
\end{tabular}

Table 10. Firm Size and Performance of R\&D

\begin{tabular}{|c|c|c|c|c|c|c|}
\hline \multirow{2}{*}{ Firm size } & & & \multicolumn{4}{|c|}{ Performance of $R \& D$} \\
\hline & Very high & High & Moderate & Low & Very Low & Total \\
\hline Large & $4(50.0 \%)$ & $4(50.0 \%)$ & $0(0.0 \%)$ & $0(0.0 \%)$ & $0(0.0 \%)$ & 8 \\
\hline Medium & $4(16.7 \%)$ & $8(33.3 \%)$ & $0(0.0 \%)$ & $12(50.0 \%)$ & $0 \quad(0.0 \%)$ & 24 \\
\hline Small & $4(5.9 \%)$ & $4(5.9 \%)$ & $30(44.1 \%)$ & $20(29.4 \%)$ & $10(14.7 \%)$ & 68 \\
\hline Total & 12 & 16 & 30 & 20 & 22 & 100 \\
\hline
\end{tabular}

Chi Square is: $45.916^{*}$ df: 8

Table 11. Proportion of turnover spent on R\&D in the last few years

\begin{tabular}{|c|c|c|c|c|c|c|}
\hline \multirow{2}{*}{ Firm size } & \multicolumn{6}{|c|}{ Proportion of turnover spent on R\&D in the last few years } \\
\cline { 2 - 7 } & $\begin{array}{c}\text { Substantially } \\
\text { Decreased }\end{array}$ & $\begin{array}{c}\text { Marginally } \\
\text { Decreased }\end{array}$ & $\begin{array}{c}\text { Remained } \\
\text { Same }\end{array}$ & $\begin{array}{c}\text { Marginally } \\
\text { Increased }\end{array}$ & $\begin{array}{c}\text { Substantially } \\
\text { Increased }\end{array}$ & Total \\
\hline Large & 0 & 0 & 0 & 0 & 8 & 8 \\
\hline Medium & 0 & 0 & 0 & 20 & 4 & 24 \\
\hline Small & 0 & 12 & 32 & 24 & 0 & 68 \\
\hline Total & - & 12 & 32 & 42 & 12 & 100 \\
\hline
\end{tabular}

Chi- Square is $91.325 * *(\mathrm{df}: 8)$ 
Table 12. Impact of TRIPS on Indian Pharmaceutical Sector

\begin{tabular}{|c|c|c|c|c|c|c|c|}
\hline $\begin{array}{l}\mathrm{S} \\
\text { No }\end{array}$ & Factor Name & Factors components & $\begin{array}{l}\text { Eigen } \\
\text { Values }\end{array}$ & $\begin{array}{l}\% \text { of } \\
\text { Var. }\end{array}$ & $\begin{array}{l}\text { Item } \\
\text { loading }\end{array}$ & Mean & SD \\
\hline \multirow[t]{5}{*}{1} & \multirow{5}{*}{$\begin{array}{l}\text { TRIPS, R\& D } \\
\text { and New } \\
\text { Opportunities }\end{array}$} & In-house $\quad R \& D$ activities & \multirow[t]{5}{*}{4.355} & \multirow[t]{5}{*}{25.616} & .804 & 3.72 & 0.77 \\
\hline & & $\begin{array}{l}\text { ii. } \\
\text { Proportion of turnover spend on } \\
\text { R\&D in the last few years }\end{array}$ & & & .663 & 2.16 & 1.49 \\
\hline & & $\begin{array}{c}\text { iii. } \begin{array}{c}\text { Cost of production as a result of } \\
\text { signing of TRIPS }\end{array}\end{array}$ & & & .690 & 3.76 & 1.07 \\
\hline & & $\begin{array}{l}\text { V. Impact of TRIPS on various issues } \\
\text { related to Indian pharmaceutical industry }\end{array}$ & & & .777 & 2.36 & 1.20 \\
\hline & & $\begin{array}{l}\text { v. New Opportunities created due to } \\
\text { TRIPS }\end{array}$ & & & .779 & 2.64 & 1.52 \\
\hline \multicolumn{6}{|c|}{ Mean of TRIPS, R\& D and New Opportunities } & 2.93 & \\
\hline \multirow[t]{2}{*}{2} & \multirow{2}{*}{$\begin{array}{l}\text { Products under } \\
\text { DPCO and } \\
\text { Performance of } \\
\text { R\& D }\end{array}$} & $\begin{array}{l}\text { i. Impact on the no. of products of the } \\
\text { firm covered under Drugs Price Control } \\
\text { Order (DPCO) }\end{array}$ & \multirow[t]{2}{*}{2.561} & \multirow[t]{2}{*}{15.067} & .891 & 3.36 & 0.84 \\
\hline & & ii. $\quad$ Performance of R\&D activities & & & .794 & 3.24 & 1.29 \\
\hline \multicolumn{6}{|c|}{ Mean of Products under DPCO and Performance of R\& D } & 3.30 & \\
\hline \multirow[t]{3}{*}{3} & \multirow{2}{*}{$\begin{array}{c}\text { Product } \\
\text { Category, Nature } \\
\text { of order \& } \\
\text { Threats }\end{array}$} & $\begin{array}{l}\text { i. } \quad \text { Impact on no. of products introduced } \\
\text { by the firm }\end{array}$ & \multirow[t]{2}{*}{2.085} & \multirow[t]{2}{*}{12.263} & .926 & 4.20 & 1.02 \\
\hline & & ii. $\quad$ Bulk orders from big companies & & & .550 & 1.88 & 0.87 \\
\hline & & $\begin{array}{l}\text { Threats due to TRIPS in form of big } \\
\text { competitions from foreign companies }\end{array}$ & & & .857 & 3.30 & 1.10 \\
\hline \multicolumn{4}{|c|}{ Mean of Product Category \& Nature of order } & & & 3.12 & \\
\hline \multirow[t]{2}{*}{4} & \multirow{2}{*}{$\begin{array}{c}\text { Changes in } \\
\text { Tech. and Tech } \\
\text { Personnel } \\
\text { Employed }\end{array}$} & Total technical persons Employed & \multirow[t]{2}{*}{1.653} & \multirow[t]{2}{*}{9.722} & .857 & 3.24 & 1.29 \\
\hline & & $\begin{array}{l}\text { ii. Shift to better technology due to } \\
\text { TRIPS }\end{array}$ & & & .618 & 3.96 & 0.87 \\
\hline \multicolumn{6}{|c|}{ Mean of Changes in No of products and Tech. } & 3.60 & \\
\hline \multirow[t]{2}{*}{5} & \multirow{2}{*}{$\begin{array}{c}\text { Changes in Total } \\
\text { Sales and } \\
\text { exports }\end{array}$} & Sales in last few years & \multirow[t]{2}{*}{1.324} & \multirow[t]{2}{*}{7.789} & .861 & 4.30 & 1.24 \\
\hline & & Exports in few year & & & .582 & 3.96 & 0.19 \\
\hline \multicolumn{6}{|c|}{ Mean of Changes in Total Sales and Exports } & 4.13 & \\
\hline \multirow[t]{2}{*}{6} & \multirow{2}{*}{$\begin{array}{l}\text { Preparedness for } \\
\text { TRIPS }\end{array}$} & Status of Patents & \multirow[t]{2}{*}{1.009} & \multirow[t]{2}{*}{5.936} & .788 & 4.14 & 0.72 \\
\hline & & Face challenges posed by TRIPS & & & .781 & 3.76 & 1.14 \\
\hline \multicolumn{6}{|c|}{ Mean of Preparedness for TRIPS } & 3.95 & \\
\hline \multicolumn{4}{|c|}{ Cumulative Variance } & 76.394 & & & \\
\hline \multicolumn{6}{|c|}{ Overall Mean of all Factors } & 3.37 & \\
\hline
\end{tabular}


Table 13. Profitability Ratios of Some Leading Pharmaceutical Firms

\begin{tabular}{|c|c|c|c|c|c|c|c|c|c|c|}
\hline & Ranbaxy & CIPLA & DRL & Lupin & Cadila & Wockhardt & Orchid & $\begin{array}{c}\text { Nicholas } \\
\text { Piramal }\end{array}$ & Sun & Aurobindo \\
\hline 1995 & 11.4 & 11.1 & 18.0 & 13.2 & 6.2 & 16.9 & 12.3 & 12.0 & 16.5 & 7. \\
\hline 1996 & 10.4 & 10.9 & 17.7 & 14.3 & 7.6 & 12.5 & 13.2 & 12.4 & 15.9 & 7.2 \\
\hline 1997 & 13.1 & 19.6 & 15.2 & 17.8 & 9.5 & 15.1 & 18.1 & 6.0 & 16.6 & 8.1 \\
\hline 1998 & 14,3 & 20.4 & 11.2 & 18.1 & 9.6 & 13.2 & 13.5 & 12.5 & 16.7 & 9.1 \\
\hline 1999 & 8.1 & 22 & 13.3 & 18.4 & 9.7 & 12.8 & 13.1 & 19.6 & 16.9 & 11.4 \\
\hline 2000 & 6.7 & 20.2 & 14 & 4.6 & 11.0 & 16.9 & 9.5 & 8.3 & 17.4 & 14.3 \\
\hline 2001 & 8.3 & 20.5 & 21.3 & 13.7 & 11.3 & 16.1 & 13.4 & 11.7 & 21.7 & 11.4 \\
\hline 2002 & 18.7 & 20.3 & 32.6 & 16.7 & 11.2 & 17.4 & 7.0 & 10.3 & 23.4 & 9.9 \\
\hline 2003 & 19 & 18.4 & 23.5 & 13.7 & 11.5 & 22.2 & 8.1 & 13.7 & 27.8 & 13.8 \\
\hline 2004 & 12.3 & 18.5 & 15.4 & 18.9 & 9.1 & 21.1 & 8.2 & 13.3 & 18.4 & 14.5 \\
\hline 2005 & 16.7 & 19.8 & 16.3 & 19.1 & 11.4 & 23.2 & 11.8 & 14.1 & 19.9 & 15.5 \\
\hline
\end{tabular}

Source: Computed from Annual Reports

Table 14. World Wide Patent Filing

\begin{tabular}{|c|c|c|c|c|c|c|c|c|c|c|c|}
\hline \multicolumn{12}{|c|}{ World Wide Patent Filing } \\
\hline & Ranbaxy & CIPLA & DRL & Lupin & Cadila & Wockhardt & Orchid & $\begin{array}{c}\text { Nicholas } \\
\text { Piramal }\end{array}$ & Sun & Aurobindo & Total \\
\hline 1999 & 14 & 0 & 3 & 12 & 1 & 2 & 0 & 0 & 1 & 0 & 33 \\
\hline 2000 & 31 & 5 & 5 & 9 & 2 & 0 & 1 & 0 & 0 & 0 & 53 \\
\hline 2001 & 53 & 15 & 5 & 8 & 3 & 3 & 1 & 1 & 2 & 0 & 91 \\
\hline 2002 & 69 & 12 & 25 & 8 & 9 & 14 & 7 & 7 & 0 & 5 & 156 \\
\hline 2003 & 127 & 21 & 69 & 12 & 14 & 14 & 31 & 4 & 2 & 6 & 300 \\
\hline 2004 & 208 & 38 & 77 & 25 & 19 & 18 & 48 & 8 & 8 & 9 & 458 \\
\hline 2005 & 259 & 56 & 49 & 32 & 29 & 25 & 25 & 11 & 4 & 2 & 492 \\
\hline
\end{tabular}

Source: EPO 
Table 15. Exports and R\&D Expenses (Rs crores)

\begin{tabular}{|c|c|c|c|}
\hline S No & Year & Exports & R\& D Expenses \\
\hline 1 & $1981-82$ & 122 & 29.3 \\
\hline 2 & $1982-83$ & 112.2 & 32.2 \\
\hline 3 & $1983-84$ & 155.2 & 40 \\
\hline 4 & $1984-85$ & 234.2 & 42.6 \\
\hline 5 & $1985-86$ & 157.9 & 48 \\
\hline 6 & $1986-87$ & 161.3 & 50 \\
\hline 7 & $1987-88$ & 326.1 & 51 \\
\hline 8 & $1988-89$ & 473.7 & 54 \\
\hline 9 & $1989-90$ & 849.6 & 56 \\
\hline 10 & $1990-91$ & 1014.1 & 60 \\
\hline 11 & 1991-92 & 1550.1 & 80 \\
\hline 12 & $1992-93$ & 1533 & 95 \\
\hline 13 & 1993-94 & 2009.7 & 125 \\
\hline 14 & 1994-95 & 2512.3 & 140 \\
\hline 15 & $1995-96$ & 3408.7 & 160 \\
\hline 16 & $1996-97$ & 4341.8 & 185 \\
\hline 17 & $1997-98$ & 5419.3 & 220 \\
\hline 18 & $1998-99$ & 6256.7 & 260 \\
\hline 19 & 1999-00 & 6631.45 & 320 \\
\hline 20 & $2000-01$ & 8757.47 & 370 \\
\hline 21 & $2001-02$ & 9751.2 & 435 \\
\hline 22 & $2002-03$ & 12826.1 & 672 \\
\hline 23 & 2003-04 & 15213.24 & 1054 \\
\hline 24 & $2004-05$ & 17857.8 & 1124 \\
\hline 25 & $2005-06$ & 22578.98 & 1235 \\
\hline \multirow[t]{4}{*}{26} & $2006-07$ & 24942 & 1430 \\
\hline & Growth Rate & 9.02 & 6.05 \\
\hline & Period I Pre TRIPS & 4.90 & 3.88 \\
\hline & Period II Post TRIPS & 5.03 & 5.07 \\
\hline
\end{tabular}

Source: Indiastat.com 
Table 16. Patenting Scenario in Post TRIPs Period

\begin{tabular}{|c|c|c|c|}
\hline Year & $\begin{array}{c}\text { Patents Granted to Drugs } \quad \& \\
\text { Pharmaceuticals ( 1) }\end{array}$ & $\begin{array}{c}\text { Total Patents Granted } \\
\text { (2) }\end{array}$ & 1 as $\%$ of 2 \\
\hline 1994-95 & 232 & 1759 & 13.19 \\
\hline $1995-96$ & 132 & 1533 & 8.611 \\
\hline 1996-97 & 71 & 907 & 7.828 \\
\hline $1997-98$ & 291 & 1844 & 15.78 \\
\hline 1998-99 & 150 & 1800 & 8.333 \\
\hline 1999-00 & 307 & 1881 & 16.32 \\
\hline 2000-01 & 276 & 1318 & 20.94 \\
\hline 2001-02 & 320 & 1591 & 20.11 \\
\hline $2002-03$ & 312 & 1379 & 22.63 \\
\hline 2003-04 & 419 & 2469 & 16.97 \\
\hline $2004-05$ & 453 & 3021 & 14.99 \\
\hline $2005-06$ & 457 & 4320 & 10.58 \\
\hline 2006-07 & 798 & 7539 & 10.58 \\
\hline 2007-08 & 1469 & 15261 & 9.626 \\
\hline $\begin{array}{c}\text { Growth } \\
\text { Rate }\end{array}$ & 6.06 & 5.57 & \\
\hline
\end{tabular}

Source: Indiastat.com 